\title{
Nutrient intake of infants and toddlers in the United Arab Emirates: the Feeding Infants and Toddlers Study
}

\author{
Y.M. Abdulrazzaq, ${ }^{7}$ N. Nagelkerke, ${ }^{2}$ S. Abdulla ${ }^{3}$ and G. Belhaj ${ }^{4}$
}

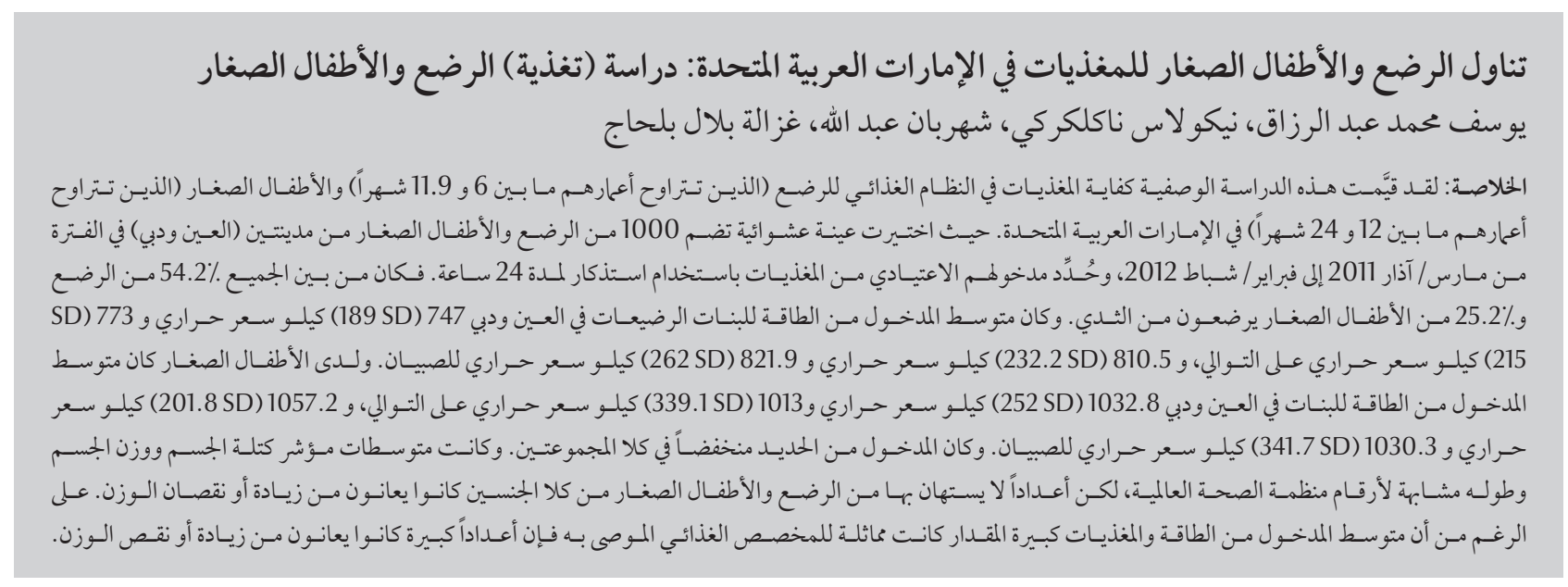

ABSTRACT This descriptive study evaluated the nutrient adequacy of the diet of infants (aged 6-11.9 months) and toddlers (aged 12-24 months) in the United Arab Emirates. A random sample of 1000 infants and toddlers was recruited from 2 cities (Al Ain and Dubai) from March 2011 to February 2012 and their usual nutrient intake was determined using 24-hour recall. In all, 54.2\% of infants and 25.2\% of toddlers were breastfeeding. Mean energy intake of infant girls in Al Ain and Dubai was 747 (SD 189) kcal and 773 (SD 215) kcal respectively and 810.5 (SD 232.2) kcal and 821.9 (SD 262) kcal for boys. In toddlers, mean energy intake for girls in Al Ain and Dubai was 1032.8 (SD 252) kcal and 1013 (SD 339.1) kcal respectively and 1057.2 (SD 201.8) kcal and 1030.3 (SD 341.7) kcal for boys. Iron intake was low in both groups. Mean body mass index and body weight and height were similar to World Health Organization figures but significant numbers of infants and toddlers of both sexes were over- or underweight. Although mean energy and macronutrient intakes were comparable to the RDA, significant numbers were over- or underfed.

Apport nutritionnel des nourrissons et des jeunes enfants aux Émirats arabes unis : étude sur l'alimentation des nourrissons et des jeunes enfants

RÉSUMÉ La présente étude descriptive avait pour objectif d'évaluer la valeur nutritionnelle de l'alimentation des nourrissons (6 à 11,9 mois) et des jeunes enfants (12 à 24 mois) aux Émirats arabes unis. Un échantillon aléatoire de 1000 nourrissons et de jeunes enfants a été sélectionné dans deux villes (Al-Aïn et Dubaï) entre mars 2011 et février 2012, et leur apport nutritionnel habituel a été déterminé au moyen du rappel des $24 \mathrm{~h}$. Au total, 54,2\% des nourrissons et 25,2 \% des jeunes enfants étaient allaités au sein. L'apport énergétique moyen des nourrissons de sexe féminin à Al-Aïn et Dubaï était de $757 \mathrm{kcal}$ (ET189) et de $773 \mathrm{kcal}$ (ET 215) respectivement, et de 810,5 kcal (ET 232,2) et de 821,9 kcal (ET 262) pour les nourrissons de sexe masculin. Concernant les jeunes enfants, l'apport énergétique moyen des petites filles à Al-Aïn et Dubaï était de 1032,8 kcal (ET 252) et de 1013 kcal (ET 339,1) respectivement, et de 1057,2 kcal (ET 201,8) et de 1030,3 kcal (ET 341,7) pour les petits garçons. L'apport en fer était faible dans les deux groupes. L'index de masse corporelle ainsi que le poids corporel et la taille moyens étaient similaires aux chiffres de l'Organisation mondiale de la Santé, mais un nombre important de nourrissons et de jeunes enfants des deux sexes étaient en surpoids ou souffraient au contraire d'insuffisance pondérale. Bien que l'apport énergétique et l'apport en macronutriments moyens étaient comparables aux apports journaliers recommandés, un nombre important des sujets étaient sur ou sous-alimentés.

${ }^{7}$ Department of Paediatrics, College of Medicine and Health Sciences, UAE University, Al Ain, United Arab Emirates (Correspondence to: Y.M. Abdulrazzaq:yousef@uaeu.ac.ae). ${ }^{2}$ Department of Community Medicine, College of Medicine and Health Sciences, United Arab Emirates University, Al Ain, United Arab Emirates. ${ }^{3}$ Latifa Hospital, Dubai, United Arab Emirates. ${ }^{4}$ Al Ain Hospital, Al Ain, United Arab Emirates.

Received: 15/06/15; accepted: 27/03/16 


\section{Introduction}

The first 2 years of a child's life are critical in cognitive, social, physical and emotional development. The type of nutrition provided during this period plays an important part in achieving the required growth and development, as well as determining the type of future food preferences, eating habits and health. Little is known about the eating habits of children in this age group in the United Arab Emirates (UAE), especially how subgroups of different ages vary in their food consumption and nutrient intake. A study from the UAE (1) showed that $60 \%$ of infants aged 5 months and $37 \%$ of those aged 12 months were breastfeeding. About $90 \%$ of infants were introduced to complementary foods between 4 and 6 months old - the period recommended by the American Academy of Pediatrics. In comparison, only $30 \%$ of sub-Saharan African children aged $<6$ months were breastfeeding (2), despite compelling evidence of the life-saving benefits of exclusive breastfeeding during this period (3). Exclusive breastfeeding and nutritive complementary feeding are known to reduce mortality in young children. In fact, 600000 deaths per year ( $6 \%$ of deaths) could be prevented by providing nourishing complementary feeding (4). It is mostly infants and toddlers who suffer the most from malnutrition and consequently are at highest risk for morbidity and mortality (4).

WHO has published guidelines for complementary feeding that include daily intake of animal-source food after 6 months of age (5). Interventional studies have not looked at local traditional food-based strategies for prevention of micronutrient deficiencies, and many people do not have access to fortified food or supplements $(6,7)$. Publications from the Middle East have especially been devoid of studies on feeding of infants and toddlers. The aim of the present study was to assess the nutrient adequacy of the diets of infants and toddlers aged 6-24 months in the UAE.

\section{Methods}

\section{Study design}

The UAE Feeding Infants and Toddlers Study (FITS) consisted of one interview, conducted in person during which both the household interview questionnaire and the 24-hour recall interview questionnaire were completed, from March 2011 to February 2012. Over $96 \%$ of children are vaccinated under the Expanded Programme on Immunization in government-run clinics and primary health care centres. Therefore, these are ideal places to recruit children in different age groups as they provide good coverage of the target population. We used the governmentrun primary health care centres of 2 cities in the Emirates of Dubai and Abu Dhabi (Dubai and Al Ain) to recruit study participants. The cities selected represent urban (Dubai) and rural (Al Ain) areas of the UAE.

Interviewers asked parents (or the most knowledgeable adult) about all foods and liquids that the infants and toddlers consumed from midnight to midnight on the following day. The dietary recall also asked about the use of vitamin and mineral supplements. We reviewed all 24-hour recalls for missing foods, unrealistic quantities reported, supplement use including brand name and type, and breastfeeding status. We used several databases to assign values to the constituents of each food. The type and amount of food in each meal were recorded and subsequently translated into nutritional contents/values using standard nutrition tables. For breast milk, the basis of the estimated intakes derived for carbohydrate, fat and protein was the sum of the content of the nutrient provided by $600 \mathrm{~mL} /$ day of human milk, which is the average volume of milk reported from studies of infants receiving human milk in this age category $(8,9)$ divided by 4 (average number of feeds). Although the amount of breast milk varies between feeds, in established breastfeeding, the amount is expected to be stable, thus, $150 \mathrm{~mL}$ per feed was the amount used to calculate breast milk consumption.

\section{Ethical review}

All data collected from the participants were strictly confidential and anonymous. Written informed consent was obtained from the primary care givers and an approval was obtained from the heads of the primary healthcare centres. Ethics approval was granted by the Ethics Committee of the College of Medicine and Health Sciences of the UAE University and of the Dubai Health Authority.

\section{Participants}

To compare a binary variable that occurred in 5\% of children in 1 group and $10 \%$ in the other group, with a 2 -sided significance level of $5 \%$ and power of $80 \%$, we needed 475 children per group. Taking into account possible losses, we decided to sample 500 in each group. Families were recruited consecutively from the infants attending primary health care centres for immunization, until the number needed was attained. The study included only infants born to UAE national fathers. Infants of all other nationalities were excluded. A sample of 500 infants and toddlers was selected from Dubai and an equal number from Al Ain. There were 500 infants aged 6-11.9 months and 500 toddlers aged 12-24 months.

\section{Main outcome measures}

The main outcome measures were total 24-hour food intake, and energy, protein, carbohydrate, fat and mineral content of the food consumed by infants and toddlers.

\section{Statistical analysis}

Data were entered into a Microsoft Excel spreadsheet and then transferred to 
SPSS, version 20 for statistical analysis. As types of food were recorded as string variables, a special routine was written to translate these into presence/absence of certain food items, for example, whether the string "purée" occurred. Data were aggregated over the entire day of observation to obtain representative values for daily intake of nutrients and food items.

Intakes of energy and macro- and micronutrients were compared to reference values. Children (20/925) with daily energy intake $<50 \%$ of recommended values were excluded because the chosen day was most likely atypical (e.g. due to illness).

Body weight and height were both translated into percentiles and $z$ values using both the Centers for Disease Control and Prevention (using Epi Info) and WHO reference values $(10,11)$. For further descriptive analysis, standard statistical graphs such as histograms, bar charts, error-bar charts and line charts, as well as means and standard deviations were used. For inferential statistical analysis, the parametric 2-sample $t$ test and $\chi^{2}$ test were used. The data were approximately normally distributed and therefore we used the Student $t$ test to determine the significance $(P<$ 0.05 ) of any differences in mean values. Means and standard errors, percentile distributions and percentages by age group (6-11.9 and 12-24 months) were calculated. $z$ scores were calculated for body mass index (BMI) and body height and weight of the sample studied. We calculated $150 \%$ and $70 \%$ recommended daily allowance (RDA) for each nutrient.

\section{Results}

A total of 905 infants and toddlers (432 girls and 473 boys) was studied after data cleaning and excluding those with incomplete or incorrect information. $z$ scores were calculated for BMI and body height and weight of the study sample and compared to WHO data (12). Although mean values were similar to the WHO data, there were significant numbers of infants and toddlers of both sexes who were significantly overweight or underweight (Figure 1). Two hundred and thirty two (54.2\%) infants and 120 (25.2\%) toddlers were breastfeeding (Figure 2). For infants $<12$ months of age and for toddlers aged 12-24 months, mean intake exceeded the adequate intake for all nutrients except for iron (Tables 1 and $2)$. There were significant differences in some of the nutrient intakes between the children in the 2 cities. For example carbohydrate intake was significantly higher in infants of both sexes from Dubai than they were in infants from $\mathrm{Al}$

Ain, but was significantly higher in only female toddlers from Dubai. However calcium, iron and phosphate intakes were significantly higher in both infants and toddlers from $\mathrm{Al}$ Ain. The mean energy intake of infant girls from $\mathrm{Al}$ Ain and Dubai was 747 (SD 189) and 773 (SD 215) kcal, respectively, compared with 810.5 (SD 232.2) and 821.9 (SD 262) for infant boys (Table 1). In toddlers, mean energy intake for girls from Al Ain and Dubai was 1032.8 (SD 252) and 1013 (SD 339.1) kcal, respectively, compared with 1057.2 (SD 201.8) and 1030.3 (SD 341.7) for boys (Table 1). Mean energy intake exceeded the estimated energy requirement by $9 \%$ for infants aged 6-11.9 months, and by $1 \%$ for toddlers aged $12-24$ months

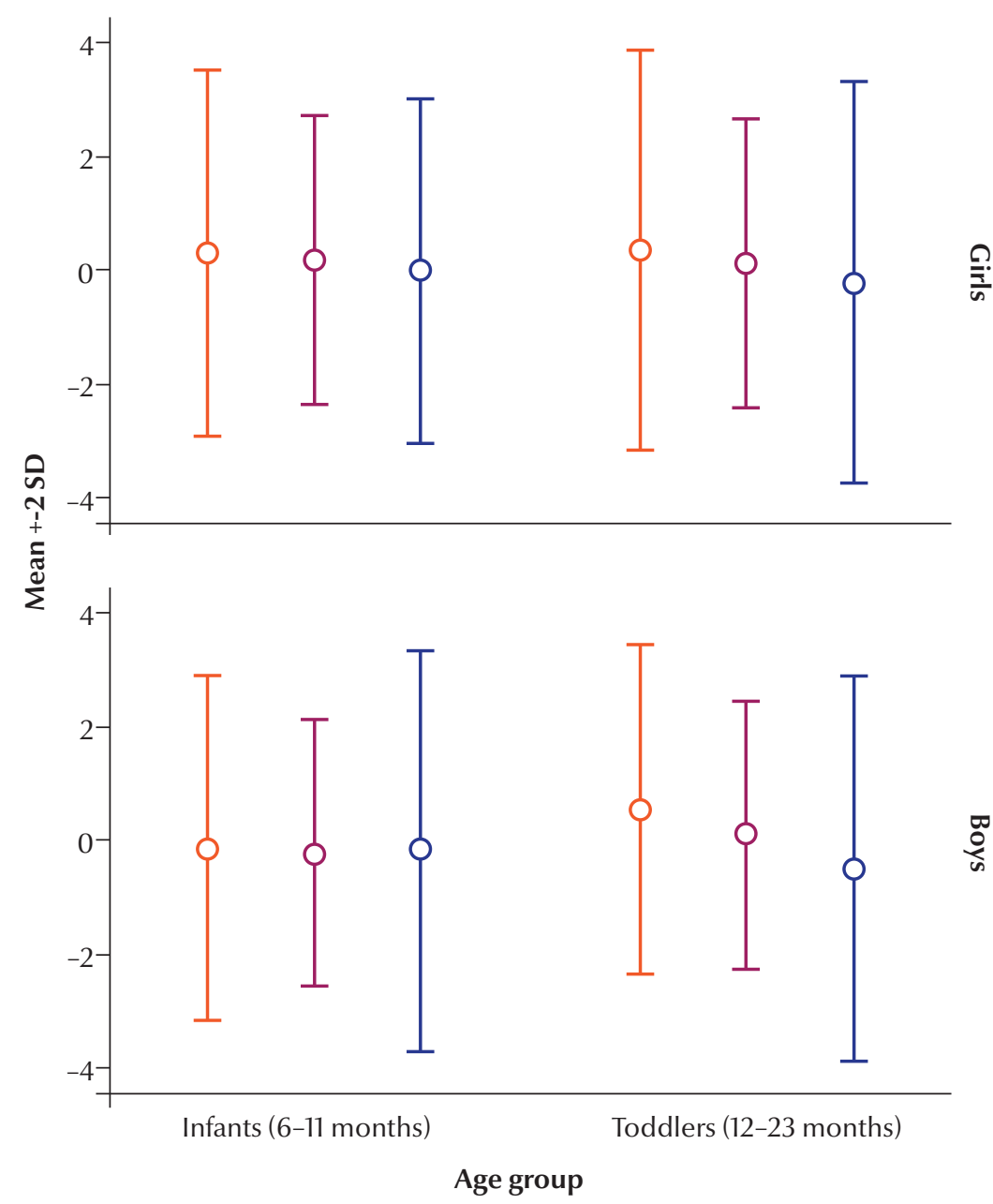

Figure 1 z scores for body mass index (BMI), weight and height in Emirati infants and toddlers studied compared to WHO data (mean BMI, weight and height which is the 0 value in the figure) (15) (SD = standard deviation) 


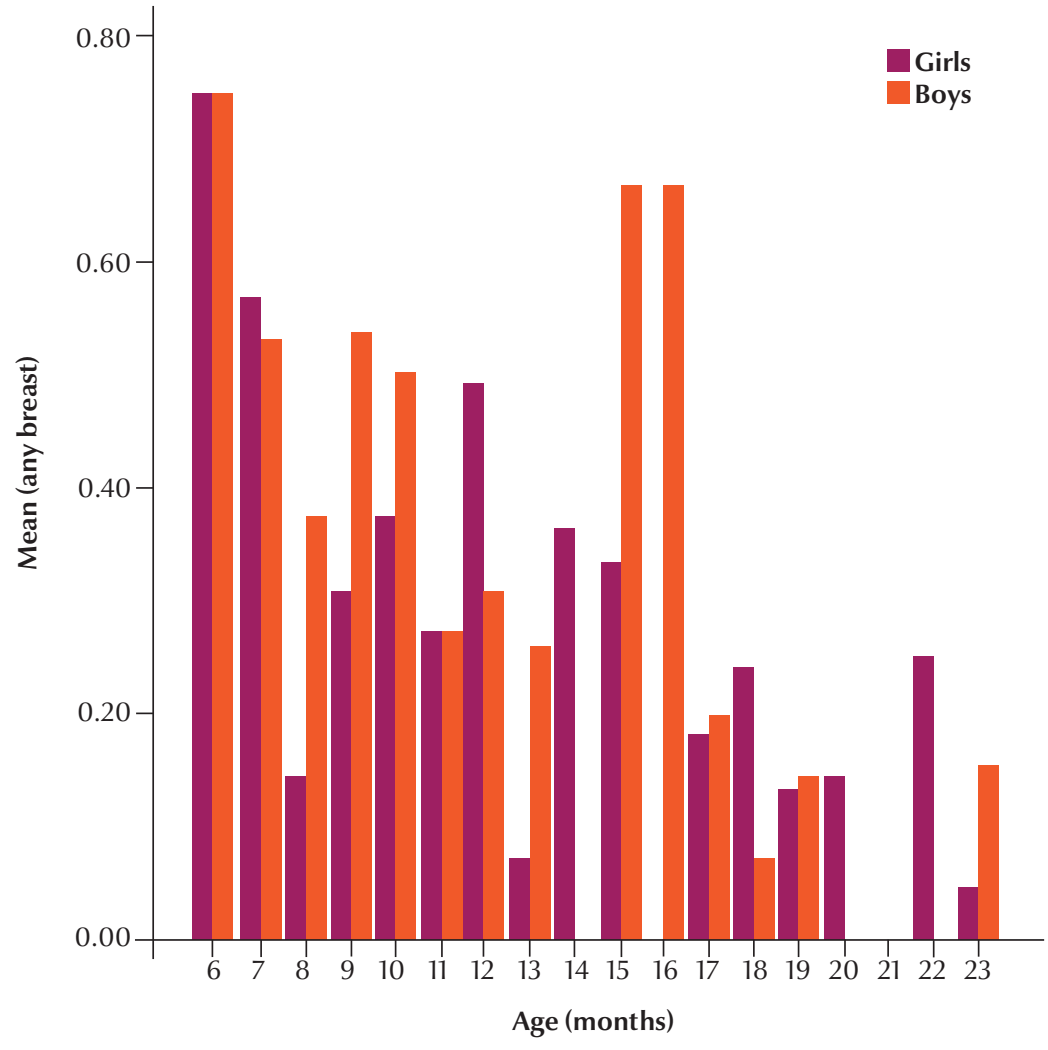

Figure 2 Number of breast fed Emarati infants and toddlers at different ages divided according to sex

(Table 2). Nine point three percent of infants and $6.3 \%$ of toddlers had energy and protein intakes $>150 \%$ of RDA for age, while $15.9 \%$ of infants and $6.9 \%$ of toddlers had carbohydrate intakes $>150 \%$ of RDA, and $8.4 \%$ of infants and $6.7 \%$ of toddlers had fat intakes $>150 \%$ of RDA (Table 3). Four point two percent of infants and $9.6 \%$ of toddlers had energy and protein intakes $<70 \%$ of RDA, while $16.6 \%$ of infants and $29.8 \%$ of toddlers had fat intakes $<70 \%$ of RDA, and $8.4 \%$ of infants and $17.5 \%$ of toddlers had carbohydrate intakes of $<70 \%$ of RDA (Table 3). Sixty-six point eight percent of infants and 100\% of toddlers had iron intakes $<70 \%$ of RDA (Table 3).

\section{Discussion}

Although 24-hour dietary recall is the optimal method for assessing usual dietary intake of population groups, there is some degree of reporting bias in intake studies relying on this method (13). There is an underestimate of energy intake in the general population but an overestimation in infants and toddlers. Our interviewers were trained to note amounts actually consumed and not what was served or spilled or wasted. These were subtracted from the total amount offered. The interviewers were provided with a portion size aid for reporting amounts of foods and beverages consumed, with depictions of cups, bowls and utensils to reflect accurately currently available items. A simple form was used and pictures provided for respondents to use in obtaining information about foods and beverages consumed in child care.

Most standards of dietary adequacy are defined in terms of usual intake, which is the long-term average of a person's daily intake. However, usual intake can seldom be observed directly. The UAE FITS dietary recalls provided data on observed nutrient intakes over a single 24-hour period for the entire sample. The observed daily intake does not accurately represent usual intake as it varies from day to day in a single child and from child to child. Although mean intake levels from this study are unbiased estimates of mean usual intake levels for a group of infants and toddlers, the dispersion of daily intake levels for a group will be greater than the dispersion of usual intake levels. Nusser et al. (14) therefore proposed an alternative method of estimation of usual intake by dropping the required assumption of the normal distribution of individual daily intake, which is normally skewed and non-negative, and this is the method we used to estimate the usual intake.

The present study is the first national study to determine the nutrient adequacy of infants and toddlers in the UAE. Overall, we established that infants and toddlers in the UAE generally receive adequate nutrition during this crucial period of growth, and that mothers provide their children with a strong nutritional basis for future growth. Nutrition requirements for growth and development after the first 6 months of life are not met with breast milk alone and the infants require additional complementary food (15). The intake of iron is particularly important in this period because iron stores, which are laid down during gestation, are declining (16). In the present study, there was some concern about intake of specific nutrients like iron, which was found to be deficient in most of the children, even though intake of other micronutrients was adequate. This probably reflects the high rate of consumption of non-iron fortified infant formulae. It is necessary to reinforce the message to parents of the benefits of introducing meat as a complementary food (17). Meat is also rich in bioavailable zinc, which is a limiting nutrient in some infants (18). When iron-rich, lean, non-processed red meat has been introduced, infants have shown improved iron and zinc 


\begin{tabular}{|c|c|c|c|c|c|c|c|}
\hline \multirow[t]{2}{*}{ Age group } & \multirow[t]{2}{*}{ Nutrient } & \multicolumn{3}{|c|}{ Girls } & \multicolumn{3}{|c|}{ Boys } \\
\hline & & $\begin{array}{c}\text { Al Ain } \\
\text { Mean (SD) }\end{array}$ & $\begin{array}{c}\text { Dubai } \\
\text { Mean (SD) }\end{array}$ & $P$-value & $\begin{array}{c}\text { Al Ain } \\
\text { Mean (SD) }\end{array}$ & $\begin{array}{c}\text { Dubai } \\
\text { Mean (SD) }\end{array}$ & $P$-value \\
\hline \multirow{9}{*}{$\begin{array}{l}\text { Infants } \\
\text { (6-11 months) }\end{array}$} & Energy (kcal) & 747.0 (18.9) & $773.0(215.5)$ & 0.3568 & $810.5(232.2)$ & $821.9(262)$ & 0.7250 \\
\hline & Protein $(\mathrm{g})$ & $19.3(9.5)$ & $22.4(10.2)$ & 0.0245 & 20.9 (11.9) & $21.6(10.1)$ & 0.6346 \\
\hline & Fat (g) & $33.0(7.8)$ & $29.1(9.7)$ & 0.0014 & 34.2 (12.3) & 31.3 (13.3) & 0.0846 \\
\hline & Carb (g) & $93.8(23.8)$ & $107.6(36.3)$ & 0.001 & $105.8(33.7)$ & $117.3(44)$ & 0.0236 \\
\hline & $\mathrm{Ca}$ (mg) & $485.6(245.5)$ & $380.2(146.8)$ & 0.0003 & $486.6(213)$ & 392.2(147.4) & 0.0001 \\
\hline & $\mathrm{Fe}(\mathrm{mg})$ & $7.7(5.7)$ & $6.2(4.1)$ & 0.0358 & $9.8(8.5)$ & 6.3(3.9) & 0.0001 \\
\hline & $M g(m g)$ & $74.2(37.1)$ & $97.2(41.3)$ & $<0.001$ & $79.2(34.7)$ & 98.3(47.1) & 0.0004 \\
\hline & $\mathrm{P}(\mathrm{mg})$ & 330.3 (205.1) & 355.3 (147.5) & 0.3308 & $322.2(155.6)$ & $345.4(145.5)$ & 0.2454 \\
\hline & Zn (mg) & $3.6(1.1)$ & $4.3(1.5)$ & 0.0001 & $3.8(1.4)$ & $4.3(1.6)$ & 0.0110 \\
\hline \multirow[t]{9}{*}{$\begin{array}{l}\text { Toddlers } \\
\text { (12-23 months) }\end{array}$} & Energy (kcal) & $1032.8(252)$ & $1013.8(339.1)$ & 0.3568 & $1057.2(201.8)$ & $1030.3(341.7)$ & 0.4335 \\
\hline & Protein (g) & $41.0(12.2)$ & $34.7(14.8)$ & 0.0245 & $41.6(13.1)$ & $35.2(15.3)$ & 0.0004 \\
\hline & Fat (g) & 38.7 (13.3) & $37.0(14.8)$ & 0.0014 & 37.5 (10.9) & $37.2(16.3)$ & 0.8613 \\
\hline & Carb (g) & $130.8(36.1)$ & 138.5 (52.5) & 0.001 & 139.4 (32.5) & $141.7(49.2)$ & 0.6556 \\
\hline & $\mathrm{Ca}$ (mg) & 716.1 (314.8) & $434.6(171.2)$ & 0.0003 & $681.2(269.8)$ & 476.5 (218.8) & $<0.001$ \\
\hline & $\mathrm{Fe}(\mathrm{mg})$ & $11.0(8.5)$ & $8.8(5.5)$ & 0.0358 & $10.5(7.3)$ & $9.5(6.4)$ & 0.2659 \\
\hline & $\mathrm{Mg}(\mathrm{mg})$ & $120.4(36.5)$ & $125.6(47)$ & $<0.001$ & $124.7(36.3)$ & $134.5(50.8)$ & 0.0750 \\
\hline & $\mathrm{P}(\mathrm{mg})$ & $617.8(241.1)$ & $483.0(233.1)$ & $<0.001$ & $611.0(214.1)$ & 491.5 (231.7) & $<0.001$ \\
\hline & Zn (mg) & $5.1(1.5)$ & $5.4(1.9)$ & 0.0001 & $5.1(1.3)$ & $5.6(1.9)$ & \\
\hline
\end{tabular}

Carb $=$ carbohydrate $; S=$ standard deviation.

intakes (19-21). The US FITS study indicated that infants received adequate amounts of iron (22). As in many other places, ensuring adequate iron intake after 6 months of age is a problem in the UAE, despite the easy availability of a variety of fortified complementary foods. From the present study, it is clear that most mothers prepare infant food at home and feed their infants iron-poor family meals. Cerelac (cereals with milk, Nestlé) is the most common commercially prepared food given to infants (50\% of infants aged $<1$ year and $20 \%$ of children aged $<2$ years received it). The risk of iron deficiency increases with excess reliability on cow's milk or non-iron-fortified milk formula during this period of high exogenous iron requirement.

The US FITS data in $2002(n=$ 3022, 0-24 months) and in 2008 ( $=3273,0-47$ months), showed overall adequate nutrition, however, there were concerns regarding the quality of children's diets (23). They found low intakes of total fat, vitamin E, potassium, fibre, iron and zinc and high intakes of energy, saturated fat, sodium, folate, vitamin A and zinc. Nevertheless, in some children, zinc intake fell below dietary recommendations, and yet in others, zinc and folate intake were high due to the contribution of zinc from dietary supplements (23). In the 2003-2010 National Health and Nutrition Examination Survey (NHANES), high intake of sodium and low intake of potassium were found in American infants and toddlers (24). Low amounts of calcium, vitamin $\mathrm{D}$, vitamin $\mathrm{C}$, magnesium, iron, fibre and potassium were consumed, while there was high consumption of sodium and saturated fat (25). In the present study, total fat intake was below the recommended levels in both infants and toddlers. Zinc, phosphorus and magnesium intakes were nearly $50 \%$ higher than the recommended amounts in toddlers and about $20 \%$ higher in infants. Calcium intake was adequate.

Between 70 and $75 \%$ of infants aged 6 months were breastfeeding, which is encouraging because breastfeeding is known to be the most effective intervention for reducing mortality in children (26). In Sub-Saharan Africa, only $30 \%$ of infants aged $<6$ months are exclusively breastfed, despite the available evidence of the life-saving benefits of exclusive breastfeeding in the first 6 months of life (27). Breastfeeding rates are on the rise in the USA, with rates of $70 \%$ at birth and $32 \%$ at 6 months in 2001 increasing to $76 \%$ at birth and $30 \%$ at 6 months in a later FITS study (28). In the 2001 National Immunization Survey, 27\% and $12 \%$ were still breastfeeding at 6 and 12 months, respectively, compared with $30 \%$ and $16 \%$ in the FITS (29). In the present study, $40 \%$ of infants were breastfeeding at 12 months of age and only $10 \%$ were still breastfeeding at 2 years of age. This rate of breastfeeding 


\begin{tabular}{|c|c|c|c|c|}
\hline \multirow[t]{2}{*}{ Age group/Nutrient } & \multicolumn{2}{|c|}{ Girls } & \multicolumn{2}{|c|}{ Boys } \\
\hline & $\begin{array}{c}\text { Al Ain } \\
\text { Mean (SD) }\end{array}$ & $\begin{array}{c}\text { Dubai } \\
\text { Mean (SD) }\end{array}$ & $\begin{array}{c}\text { Al Ain } \\
\text { Mean (SD) }\end{array}$ & $\begin{array}{c}\text { Dubai } \\
\text { Mean (SD) }\end{array}$ \\
\hline \multicolumn{5}{|l|}{ Infants (6-11 mo) } \\
\hline Frac Energy & $1.11(0.22)$ & $1.14(0.32)$ & $1.09(0.31)$ & $1.11(0.35)$ \\
\hline Frac Protein & $1.11(0.22)$ & $1.14(0.32)$ & $1.09(0.31)$ & $1.11(0.35)$ \\
\hline Frac Fat & $1.10(0.26)$ & $0.97(0.32)$ & $1.01(0.36)$ & $0.92(0.39)$ \\
\hline Frac Carb & $1.04(0.26)$ & $1.20(0.40)$ & $1.06(0.34)$ & $1.17(0.44)$ \\
\hline Frac Ca & $1.80(0.91)$ & $1.41(0.54)$ & $1.80(0.79)$ & $1.45(0.55)$ \\
\hline Frac Fe & $0.70(0.52)$ & $0.56(0.38)$ & $0.89(0.77)$ & $0.57(0.35)$ \\
\hline Frac Mg & $0.99(0.49)$ & $1.30(0.55)$ & $1.06(0.46)$ & $1.31(0.63)$ \\
\hline Frac $P$ & $1.20(0.75)$ & $1.29(0.54)$ & $1.17(0.57)$ & $1.26(0.53)$ \\
\hline Frac Zn & $1.21(0.36)$ & $1.42(0.49)$ & $1.27(0.47)$ & $1.43(0.51)$ \\
\hline \multicolumn{5}{|l|}{ Toddlers (12-23 mo) } \\
\hline Frac Energy & $1.04(0.25)$ & $1.02(0.34)$ & $1.01(0.19)$ & $0.99(0.33)$ \\
\hline Frac Protein & $1.04(0.25)$ & $1.02(034)$ & $1.01(0.19)$ & $0.99(0.33)$ \\
\hline Frac Fat & $0.97(0.33)$ & $0.93(0.37)$ & $0.85(0.25)$ & $0.85(0.37)$ \\
\hline Frac Carb & $1.01(0.28)$ & $1.07(0.40)$ & $0.93(0.22)$ & $0.94(0.33)$ \\
\hline Frac Ca & $1.43(0.63)$ & $0.87(0.34)$ & $1.36(0.54)$ & $0.95(0.44)$ \\
\hline Frac Fe & $0.16(0.12)$ & $0.13(0.08)$ & $0.15(0.10)$ & $0.14(0.09)$ \\
\hline Frac Mg & $1.50(0.46)$ & $1.57(0.59)$ & $1.56(0.45)$ & $1.68(0.63)$ \\
\hline Frac $P$ & $1.34(0.52)$ & $1.05(0.51)$ & $1.33(0.47)$ & $1.07(0.50)$ \\
\hline Frac Zn & $1.69(0.50)$ & $1.81(0.62)$ & $1.70(0.43)$ & $1.87(0.64)$ \\
\hline
\end{tabular}

Carb = carbohydrate; Frac = fraction $; S D=$ standard deviation .

was lower than in 2000, when $49.7 \%$ continued breastfeeding at 1 year of age and $28.9 \%$ were still breastfeeding at 2 years of age (30). In that study, $93.2 \%$ of infants had ever breastfed and $23.2 \%$ had early initiation (within 1 hour of birth) of breastfeeding. The well-baby clinics, like most hospitals in the UAE, follow WHO/UNICEF Baby Friendly Hospital Initiative (31) in their counselling of mothers on breastfeeding. This is probably one of the reasons why such a large percentage of infants are breastfed at 6 months of age and beyond.

Although mean energy and protein intakes were close to the required daily intakes, there were significant numbers of toddlers and infants receiving high intakes of protein and energy or lower intakes than the RDA. There were no significant differences between intakes in infants and toddlers in the 2 cities of the UAE, one representing an urban and the other a rural area. However, children in Al Ain consumed more fatty food and less carbohydrate than their counterparts in Dubai. Mean energy intake exceeded the estimated energy requirement by $23 \%$ for infants aged 6-11.9 months and $31 \%$ for toddlers aged 12-24 months. Dairy intake, specifically milk, provided the most energy to the diet in infants and toddlers. The growth of the infants and toddlers in the present study does not lend support to the suggestion that there was underreporting or over-reporting, as $z$ scores were nearly 0 at all ages. However, the range of $z$ scores was wide, meaning that there were many infants and toddlers who were either heavy or light for their age. The US FITS participants had higher weight-for-age percentiles than the participants in the Centers for Disease Control and Prevention study (10) and therefore may have had higher energy intakes. The authors concluded that, although paediatric obesity was multifactorial in aetiology, excessive energy intake would certainly contribute to the increasing prevalence of obesity.

The strength of the present study was that the sample was representative of the population, as children were recruited from a large city and a small town to represent both urban and rural areas. The limitations of the study were the same as in other studies of this type. Food intake could have been under- or over-reported. Assumptions are made as to the amount of foods taken. Although it is well known that ready-made foods provide reasonably accurate measurements of their constituents, contents of locally prepared meals were estimated according to published figures, which may not be an accurate reflection of the true contents of the food. However, this did not affect 


\begin{tabular}{|c|c|c|c|c|c|c|}
\hline \multirow[t]{2}{*}{ Nutrient } & \multicolumn{3}{|c|}{$<70 \%$ intake } & \multicolumn{3}{|c|}{$>150 \%$ intake } \\
\hline & $\begin{array}{c}\text { Infants } \\
\text { (6-11 months) } \\
\%\end{array}$ & $\begin{array}{c}\text { Toddlers } \\
\text { (12-23 months) } \\
\%\end{array}$ & $\begin{array}{c}\text { Total } \\
\%\end{array}$ & $\begin{array}{c}\text { Infants } \\
\text { (6-11 months) } \\
\%\end{array}$ & $\begin{array}{c}\text { Toddlers } \\
\text { (12-23 months) } \\
\%\end{array}$ & $\begin{array}{c}\text { Total } \\
\%\end{array}$ \\
\hline Energy & 4.2 & 9.6 & 7.1 & 9.3 & 6.5 & 7.8 \\
\hline Protein & 4.2 & 9.6 & 7.1 & 9.3 & 6.5 & 7.8 \\
\hline Fat & 16.6 & 29.8 & 23.5 & 8.4 & 6.7 & 7.5 \\
\hline Carbohydrate & 6.8 & 15.1 & 11.2 & 15.9 & 6.9 & 11.2 \\
\hline $\mathrm{Ca}$ & 2.8 & 23.5 & 13.7 & 44.9 & 20.1 & 31.8 \\
\hline $\mathrm{Fe}$ & 66.8 & 100 & 84.3 & 7.9 & 0.0 & 3.8 \\
\hline $\mathrm{Mg}$ & 19.9 & 1.5 & 10.2 & 25.5 & 52.4 & 39.7 \\
\hline$P$ & 16.4 & 15.9 & 16.1 & 27.6 & 21.8 & 24.5 \\
\hline $\mathrm{Zn}$ & 3 & 0.4 & 1.7 & 30.7 & 62.2 & 47.3 \\
\hline
\end{tabular}

the results greatly as the infants were usually fed well-know infant foods, with known constituents.

\section{Conclusion}

While the mean intake of macronutrients was near recommended levels, there was a significant percentage of infants and toddlers who received either more or less than the RDA for their age. This means that a significant percentage of infants and toddlers were either under- or over-nourished and this could have a significant impact on future growth and development. The amount of iron received in the majority of infants and toddlers was also inadequate.
Funding: Funding of the project was from a grant by Nestlé Nutrition. The study design was the same as the FITS USA study and was provided by Nestlé Nutrition. However, Nestlé Nutrition had no role or involvement in collection of data, data analysis, interpretation of data, preparation of the manuscript, or decision to send it for publication.

Competing interests: None declared.

\section{References}

1. Abdulrazzaq YM, Nagelkerke N, Belhaj G, Abdulla S. Nutrient adequacy of the diets of UAE infants and toddlers-FITS study, UAE. Poster A-486-0007-00585; 2012: The $4^{\text {th }}$ Congress of the European Academy of Paediatric Societies.

2. World Health Organization. The optimal duration of exclusive breastfeeding: a systematic review. Geneva: World Health Organization; 2002.

3. The state of the world's children 2006 - excluded and invisible. New York: United Nations Children's Fund; 2005.

4. Jones G, Steketee RW, Black RE, Bhutta ZA, Morris SS; Bellagio Child Survival Study Group. How many child deaths can we prevent this year? Lancet 2003;362(9377):65-71. PMID:12853204

5. Guiding principles for complementary feeding of the breastfed child. Washington, DC: Pan American Health Organization/World Health Organization; 2003.

6. Penny ME, Creed-Kanashiro HM, Robert RC, Narro MR, Caulfield LE, Black RE. Effectiveness of an educational intervention delivered through the health services to improve nutrition in young children: a cluster-randomised controlled trial. Lancet. 2005 May 28;365(9474):1863-72. PMID:15924983

7. Guldan GS, Fan HC, Ma X, Ni ZZ, Xiang X, Tang MZ. Culturally appropriate nutrition education improves infant feeding and growth in rural Sichuan, China. J Nutr. 2000 May;130(5):120411. PMID:10801920

8. Dewey KG, Finley DA, Lönnerdal B. Breast milk volume and composition during late lactation (7-20 months). J Pediatr Gastroenterol Nutr. 1984 Nov;3(5):713-20. PMID:6502372
9. Heinig MJ, Nommsen LA, Peerson JM, Lonnerdal B, Dewey KG. Energy and protein intakes of breast-fed and formula-fed infants during the first year of life and their association with growth velocity: the DARLING Study. Am J Clin Nutr. 1993 Aug;58(2):152-61. PMID:8338041

10. US Department of Health and Human Services, Centers for Disease Control and Prevention, National Center for Health Statistics. CDC Growth Charts, clinical growth charts: United States. (http://www.cdc.gov/growthcharts/html_charts/ wtage.htm, accessed 1 May 2016)

11. de Onis M, Garza C, Onyango AW, Martorell R, editors. WHO child growth standards, Acta Paediatr. 2006 Apr;95 Suppl. 450.

12. WHO Multicentre Growth Reference Study Group. WHO child growth standards based on length/height, weight and age. Acta Paediatr. 2006 Apr;95 Suppl 450:76-85. PMID:16817681

13. Briefel RR, Sempos CT, McDowell MA, Chien S, Alaimo K. Dietary methods research in the third National Health and Nutrition Examination Survey: underreporting of energy intake. Am J Clin Nutr. 1997 Apr;65(4) Suppl:1203S-9S. PMID:9094923

14. Nusser SM, Carriquiry AL, Dodd KW, Fuller WA. A semiparametric transformation approach to estimating usual daily intake distributions. J Am Stat Assoc. 1996;91:1440-9.

15. Pac S, McMahon K, Ripple M, Reidy K, Ziegler P, Myers E. Development of the Start Healthy Feeding Guidelines for Infants and Toddlers. J Am Diet Assoc. 2004 Mar;104(3):455-67. PMID:14993871 
16. Baker RD, Greer FR; Committee on Nutrition American Academy of Pediatrics. Diagnosis and prevention of iron deficiency and iron-deficiency anemia in infants and young children (0-3 years of age). Pediatrics. 2010 Nov;126(5):1040-50. PMID:20923825

17. Krebs NF, WestcottJE, Butler N, Robinson C, Bell M, Hambidge KM. Meat as a first complementary food for breastfed infants: feasibility and impact on zinc intake and status. J Pediatr Gastroenterol Nutr. 2006 Feb;42(2):207-14. PMID:16456417

18. Butte N, Cobb K, Dwyer J, Graney L, Heird W, Rickard K; American Dietetic Association; Gerber Products Company. The Start Healthy Feeding Guidelines for Infants and Toddlers. J Am Diet Assoc. 2004 Mar;104(3):442-54. PMID:14993870

19. US Department of Health and Human Services. Healthy People 2010. Understanding and improving health. 2nd ed. Washington, DC: US Government Printing Office, November 2010.

20. Centers for Disease Control and Prevention. Recommendations to prevent and control iron deficiency in the United States. MMWR Recomm Rep. 1998 Apr 3;47 RR-3:1-29. PMID:9563847

21. Dewey KG, Cohen RJ, Rivera LL, Brown KH. Effects of age of introduction of complementary foods on iron status of breastfed infants in Honduras. Am J Clin Nutr. 1998 May;67(5):87884. PMID:9583845

22. Devaney B, Ziegler P, Pac S, Karwe V, Barr SI. Nutrient intakes of infants and toddlers. J Am Diet Assoc. 2004 Jan;104(1) Supp 1:s14-21. PMID:1470201327. Lartey A. Maternal and child nutrition in Sub-Saharan Africa: challenges and interventions. Proc Nutr Soc. 2008 Feb;67(1):105-8. PMID:18234138

23. Butte NF, Fox MK, Briefel RR, Siega-Riz AM, Dwyer JT, Deming DM, et al. Nutrient intakes of US infants, toddlers, and pre- schoolers meet or exceed dietary reference intakes. J Am Diet Assoc. 2010 Dec;110(12) Suppl:S27-37. PMID:21092766

24. Tian N, Zhang Z, Loustalot F, Yang Q, Cogswell ME. Sodium and potassium intakes among US infants and preschool children, 2003-2010. Am J Clin Nutr. 2013 Oct;98(4):1113-22. PMID:23966425

25. 2015 Dietary Guidelines Advisory Committee. Scientific report of the 2015 Dietary Guidelines Advisory Committee; February 2015 (https://ods.od.nih.gov/pubs/2015_DGAC_Scientific_ Report.pdf, accessed 1 May 2016)

26. Jones G, Steketee RW, Black RE, Bhutta ZA, Morris SS; Bellagio Child Survival Study Group. How many child deaths can we prevent this year? Lancet. 2003 Jul 5;362(9377):65-71. PMID:12853204

27. Lartey E. Maternal and child nutrition in Sub-Saharan Africa: challenges and interventions. Proc Nutr Soc. 2008;67:105-8.

28. Ryan AS, Wenjun Z, Acosta A. Breastfeeding continues to increase into the new millennium. Pediatrics. 2002 Dec;110(6):1103-9. PMID:12456906

29. Li R, Zhao Z, Mokdad A, Barker L, Grummer-Strawn L. Prevalence of breastfeeding in the United States: the 2001 National Immunization Survey. Pediatrics. 2003 May;111(5 Pt 2):1198201. PMID:12728138

30. WHO Global Data Bank on Infant and Young Child Feeding (IYCF). Geneva: World Health Organization; 2009.

31. Protecting, promoting and supporting breastfeeding: the special role of maternity services. Geneva: World Health Organization; 1989. 